\title{
KINIK-ELMADERE LİNYITT PROJESİ KAPSAMINDA HAVALANDIRMA VE SERVİS KUYUSU AÇMA ÇALIŞMALARININ DEĞERLENDİRİLMESİ
}

\author{
İsmail ÖZKAN ${ }^{1 *}$, Nazmi ŞENGÜN² \\ ${ }^{1}$ Polyak Eynez Enerji Üretim Madencilik San. ve Tic. A.Ş., İZMIR \\ ORCID No : http://orcid.org/0000-0002-2226-9735 \\ ${ }^{2}$ Süleyman Demirel Üniv., Mühendislik Fak., Maden Müh. Bölümü, ISPARTA \\ ORCID No : http://orcid.org/0000-0003-0407-7198
}

\begin{tabular}{|c|c|}
\hline Anahtar Kelimeler & Öz \\
\hline $\begin{array}{l}\text { Kuyu açma } \\
\text { Isş-zaman etüdü } \\
\text { Delme-patlatma } \\
\text { Beton tahkimat } \\
\text { Enjeksiyon }\end{array}$ & $\begin{array}{l}\text { Kuyu açma, yeraltı madenciliğinde hazırlık çalışmalarının önemli bir kısmını } \\
\text { oluşturmaktadır. Bu çalışmada, Türkiye'de önemli bir kömür havzası olan Soma kömür } \\
\text { havzasında Polyak Eynez Enerji Üretim Madencilik San. ve Tic. A.Ş. tarafından Kınık- } \\
\text { Elmadere'de delme patlatma yöntemiyle açılan havalandırma ve servis kuyularının kazı } \\
\text { çalışmalarının değerlendirilmesi yapılmıștır. Kuyuların kazısı öncesi yapılmış olan } \\
\text { sondaj verilerinden hareketle litolojik özellikler belirlenmiş ve kuyularının kazısı } \\
\text { sırasında her bir litolojik birim için ölçümler yapılarak gerçek veriler ortaya } \\
\text { konulmuştur. Kuyu kazıları sırasında ilerleme performansları, delme ve patlatma } \\
\text { çalışmaları, tahkimat işlemlerinin değerlendirilmesi yapılmıştır. Ayrıca kuyuların kazısı } \\
\text { sırasında karşılaşılan problemler, zayıf formasyon geçişleri ve basınçlı akifere yönelik } \\
\text { yapılan enjeksiyonlar hakkında bilgi verilmiştir. Elde edilen sonuçların Türkiye yeraltı } \\
\text { madencilik literatüründe yer alması ve ileride kuyu açma çalışmalarına ışı tutması } \\
\text { amaçlanmıștır. }\end{array}$ \\
\hline
\end{tabular}

\section{EVALUATION OF SHAFT SINKING STUDIES OF VENTILATION AND SERVICE WELLS WITHIN THE SCOPE OF KINIK-ELMADERE LIGNITE PROJECT}

\begin{tabular}{l}
\hline Keywords \\
\hline Shaft sinking \\
Work-time study \\
Drilling and blasting \\
Concrete support \\
Grouting
\end{tabular}

Keywords

Shaft sinking

Work-time study

Concrete support

routing

\begin{tabular}{|c|c|}
\hline Keywords & Abstract \\
\hline Shaft sinking & Shaft sinking is a crucial part of the underground mine preparation operations. In this \\
\hline Work-time study & study, evaluation of the ventilation and service wells shaft sinking operations by Polyak \\
\hline Drilling and blasting & Eynez Energy Product Mining Trade Inc. utilizing drill and blast technique in Kınık, \\
\hline Concrete support & Elmadere region located at Soma Basin which is the one of the most significant coal basin \\
\hline Grouting & $\begin{array}{l}\text { in Turkey is provided. Before the shaft sinking has been commenced, lithological } \\
\text { character of the area has been identified by conducted drill holes and these inputs are } \\
\text { confirmed and enhanced with the actuals data that are collected while the sinking of the } \\
\text { shafts. During the shaft operations, sinking performance, drill and blast operations, } \\
\text { support operations are evaluated. Moreover, additional information is provided as to } \\
\text { some of the problems that are encountered during the sinking such as weak strata layer } \\
\text { transitions and chemical and concrete injections through the confined aquifer zone. }\end{array}$ \\
\hline Araștırma Makalesi & Research Article \\
\hline Başvuru Tarihi & Submission Date \\
\hline Kabul Tarihi & Accepted Date \\
\hline
\end{tabular}

\section{Abstract}

Shaft sinking is a crucial part of the underground mine preparation operations. In this Eynez Energy Product Mining Trade Inc. utilizing drill and blast technique in Kınık, Elmadere region located at Soma Basin which is the one of the most significant coal basin in Turkey is provided. Before the shaft sinking has been commenced, lithological character of the area has been identified by conducted drill holes and these inputs are confirmed and enhanced with the actuals data that are collected while the sinking of the shafts. During the shaft operations, sinking performance, drill and blast operations, support operations are evaluated. Moreover, additional information is provided as to transitions and chemical and concrete injections through the confined aquifer zone.

\section{Giriş}

Derin maden yataklarında, madene ulaşmak amacıyla desandre (meyilli galeri) veya düşey kuyulardan yararlanılır. Kuyu açma işlemleri için birkaç geleneksel ve mekanize yöntem bulunmaktadır. Kuyu kazısı genellikle delme-patlatma yöntemi ile yapılırken mekanik kazı tekniğinin kullanılması, büyük bir sermaye maliyeti getirmekle birlikte, proje performansını iyileștirmek için uygulanabilir bir alternatiftir (Saltoğlu, 1976). Yeraltı madencilik çalışmalarında düşey kuyuların ana görevleri; yeraltı çalışmaları için gerekli temiz havanın, tahkimat malzemelerinin, basınçlı havanın, haberleşme ve aydınlatma amaçlı iletim hatlarının yeraltına iletilmesinde ve ayrıca yeraltından üretilen cevherin yeryüzüne nakliyesinde bir yol görevi görmektir (Hussaini ve Özkan, 2018).

Madenlerde malzeme, cevher, insan taşımak ve/veya havalandırma amacıyla kurulacak sistemler için gerekli olan kuyuların açılması genellikle zorlu bir iş

\footnotetext{
*Sorumlu yazar; e-posta : nazmisengun@sdu.edu.tr
} 
olmaktadır. Maden ocaklarının yeryüzüyle bağlantısını sağlayan kuyular, maden ocaklarının en önemli bölümleridir. Kuyu açma ve tahkimat masrafları, yeni bir maden hazırlık maliyetinin içinde oldukça önemli bir paya sahip olup kuyunun açldığı jeolojik birimlere, çapına ve derinliğine göre değişmektedir (Read ve Napier, 1994). Maden ocağının ömrü boyunca sağlam kalması gereken kuyunun maliyetinin de asgari seviyede tutulması ve iş organizasyonunun sağlıklı bir şekilde yapılması gerekmektedir.

Kuyunun açıldığı kaya kütlesi az su gelirine sahipse Şekil 1'de şematik gösterimi verilen klasik kuyu açma yöntemi uygulanır. Buna karşın, hem kaya kalitesi az hem de su geliri fazla ise özel kuyu açma yöntemlerinden birinin uygulanması zorunludur (Köse, Gürgen, Onargan, Yenice ve Aksoy, 2012). Derin maden yataklarında madene ulaşmak için gerekli olan kuyuların açılma yöntemi kullanım amacına bağlı olarak farklı yöntemlere göre olmakta ve kullanılan yöntemin avantaj ve dezavantajları değişmektedir (Tablo 1).

\section{Tablo 1}

Kuyu Açma Yöntemlerinin Avantaj ve Dezavantajları (Lashgari, Fouladgar, Yazdani-Chamzini ve Skibniewski, 2011)

\begin{tabular}{|c|c|c|c|}
\hline Metot & Kullanım & Avantajları & Dezavantajları \\
\hline$\frac{d}{\stackrel{\Xi}{\Xi}}$ & $\begin{array}{l}\text { Her türlü } \\
\text { dikey kazı } \\
\text { işlerinde }\end{array}$ & \multirow{2}{*}{$\begin{array}{l}\text { - Küçük kuyularda } \\
\text { kullanılabilir } \\
\text { - Düşük yatırım } \\
\text { maliyeti } \\
\text { - Mekanizasyon } \\
\text { gereksinimi yok } \\
\text { - Her türlü çap ve } \\
\text { uzunluk için } \\
\text { uygulanabilir }\end{array}$} & \multirow{2}{*}{$\begin{array}{l}\text { - Düşük } \\
\text { performans oranı } \\
\text { - Güvensiz } \\
\text { operasyon } \\
\text { ortamı } \\
\text { - Havalandırma } \\
\text { sistemi } \\
\text { gerekliliği }\end{array}$} \\
\hline 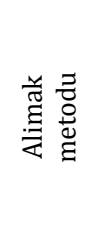 & $\begin{array}{l}\text { Boyut ve kazı } \\
\text { açısı } \\
\text { kısıtlaması } \\
\text { olmadan, } 200 \\
\text { m'den daha } \\
\text { derin } \\
\text { kazılarda }\end{array}$ & & \\
\hline 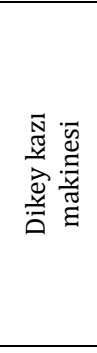 & $\begin{array}{l}1260 \text { m } \\
\text { uzunluğa } \\
\text { kadar } 0.7 \text { - } \\
7.1 \text { m çap } \\
\text { arasında } \\
\text { değișen kuyu } \\
\text { kazılarında }\end{array}$ & \multirow{2}{*}{$\begin{array}{l}\text { - Mekanize metod } \\
\text { - Yüksek kazı hızı } \\
\text { - Farklı tip delme } \\
\text { operasyonları için } \\
\text { kullanışlı } \\
\text { @ \%0,035’e kadar } \\
\text { sapma } \\
\text { doğruluğunda kazı } \\
\text { - Patlatma } \\
\text { olmadığından } \\
\text { patlatmanın yol } \\
\text { açtığı çatlaklardan } \\
\text { muaf } \\
\text { - Zamanın önemli } \\
\text { olduğu durumlarda } \\
\text { uygun maliyetli } \\
\text { - Uzun deliklerin } \\
\text { delinmesi standart } \\
\text { hale gelir }\end{array}$} & \multirow{2}{*}{$\begin{array}{l}\text { - Düz bir hat ile } \\
\text { delme sayesinde } \\
\text { esnek olmayan } \\
\text { operasyonların } \\
\text { güvenilir bir } \\
\text { şekilde } \\
\text { gerçekleşmesi } \\
\text { - Metraj maliyeti } \\
\text { yüksek } \\
\text { - Belirli boyut ve } \\
\text { uzunluk } \\
\text { sınırlaması } \\
\text { - Yüksek kazı } \\
\text { hızının fazla } \\
\text { miktarda pasa } \\
\text { alımı } \\
\text { gerektirmesi } \\
\text { - Makul } \\
\text { derecede stabil } \\
\text { zemin koşulları } \\
\text { gerektirir }\end{array}$} \\
\hline 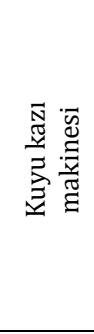 & $\begin{array}{l}8.5 \text { m çapa } \\
\text { kadar derin } \\
\text { ve dik kuyu } \\
\text { kazılarında }\end{array}$ & & \\
\hline
\end{tabular}

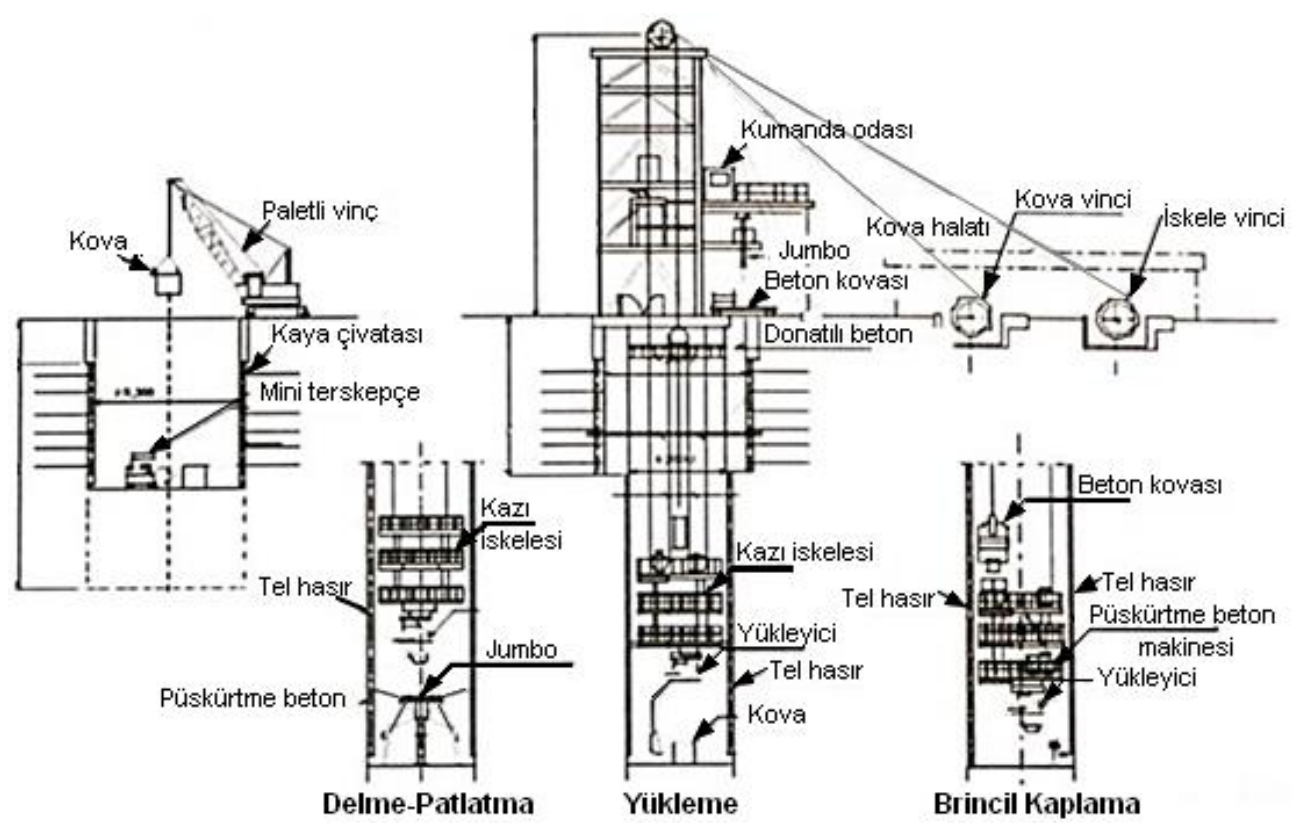

Şekil 1. Tipik Kuyu Açımı İşlem Adımları (Köse ve dĭg., 2012) 
Kınık-Elmadere bölgesinde kömür madenciliğinde gerek topoğrafik yapıdan gerekse damar yapılarından dolayı derin kotlara kuyu ile inilmesi tercih edilmiștir. $\mathrm{Bu}$ kapsamda İzmir-Kınık sınırları içerisinde Polyak Eynez Enerji Üretim Maden San. Tic. A.Ş.'ne ait Eynez (Elmadere) linyit sahasında madencilik faaliyetleri yapılması için biri servis (nakliye) diğeri havalandırma kuyusu olmak üzere iki kuyu açılması planlanmıştır. Yılda 4-4,5 milyon ton kömür üretimi planlanan KınıkElmadere linyit projesinde bu üretimi gerçekleştirmenin en önemli önşartları servis ve havalandırma kuyusunun sağlıklı bir şekilde açılmasıdır. Bu çalışmada, Eynez (Elmadere) yeni linyit sahasında havalandırma, insan ve malzeme nakliyatı için tasarlanan kuyulardan Polyak-1 (havalandırma kuyusu) ve Polyak-2 (servis kuyusu) kuyularının kazı (delme-patlatma), nakliye, tahkimat, zemin iyileștirme, iş organizasyonu ve iş sağlığı ve güvenliği açısından incelenmesi ve değerlendirilmesi amaçlanmıştır. Çalışmada, Türkiye'de gelecekte yapılacak herhangi bir kuyu inşaatına uygulanmak üzere referans alınan iş planı ve termin hesaplamalarının optimizasyonuna bir değerlendirme sağlaması amacıyla, Eynez (Elmadere) yeni linyit sahasında havalandırma ve servis kuyusunun kazısı esnasında kaydedilen gerçek döngü süresi analizi verilmiştir. Çalışmada, kuyu açımı sırasında karşılaşılan problemler ve çözümleri ortaya konmuştur. Çalışma birinci yazarın tezinden üretilmiş ve yazar söz konusu projede mühendis olarak çalışmaktadır. $\mathrm{Bu}$ nedenle makalede yasal/özel izin alınması gerekmemektedir. Makalede kaynak gösterilmeden görsel kullanılmamıştır. Makalelerde Araştırma ve Yayın Etiğine uyulmuştur.

\section{Bilimsel Yazın Taraması}

Çalışma konusu ile ilgili literatür taraması yapılmış ve konu ile ilgili çok az sayıda yerli çalışmaya rastlanmıştır. Bu çalışmalardan bazıları aşağıda özetlenmiştir.

Özdemir (1998) çalışmasında, kuyu (şaft) açma tekniklerini özetleyip karşılaştırmalar yapmış, konvansiyonel metodu daha detaylı olarak araştırmıştır. Rize-Çayeli'nde konvansiyonel metodla açılan bir kuyu çalışmasında, inşaat aşamalarını izah etmiş, kullanılan ekipman alternatiflerini ve kuyunun ilerleme hızını incelemiştir. Emir (2000) çalışmasında, G.L.İ. Hazırlık Panosu kuyu açıklığı çevresindeki kayaçların davranışını inceleyerek emniyetli ve ekonomik bir kuyu kaplama kalınlığının belirlemeye çalışmıştır. Çalışmada, kuyu kaplama kalınlığını belirlemek amacıyla Phases sayısal programı kullanılmıştır. Bayhan, Ölmez ve Arslan, (2002) yaptıkları çalışmada Kozlu bölgesinde Uzunmehmet-1 kuyusu tamir ve derinleștirme çalışmaları detaylı bir şekilde anlatmışlardır. Alp (2003) çalışmasında, Türkiye Taşkömürü Kurumu Kozlu Taşkömürü İşletme Müessesinde mevcut Kozlu Uzun Mehmet-I Kuyusunun, derinleştirme çalışmasını, inset tesisi, inset ve kuyu içi teçhizi işlerini ve ayrıca maliyet durumunu detaylı bir şekilde anlatmıştır. Acun (2009) yaptı̆̆ı çalışmada, Amasra bölgesinde özel sektör tarafindan yürütülen Amasra B projesi kapsamında yapılan üç kuyudan biri olan Tarlaağzı üretim kuyusu incelenmiş, kuyunun belirli derinliklerindeki kuyu çevresinde oluşan yer değiştirmeler ile yenilme bölgesi büyüklüklerini belirlemeye çalıșmıștır. Ayrıca uygulanan beton tahkimatının duraylılık açısından yeterliliğini değerlendirmiştir. Oruç (2012) çalışmasında, Kastamonu İli, Küre bakır işletmesinde, açlacak kuyunun ve çevresinin yerleşim modeli oluşturulmuş çeşitli analiz programları kullanılarak şaft açılması sırasında oluşabilecek düşey, yatay ve toplam deplasmanların analizleri yapılmıştır. Güler (2013) çalışmasında, dairesel kesitli maden kuyularının duraylı kalabilmesi için gerekli tahkimat kalınlığını tahmin etmeye amaçlamış ve bir bilgisayar yazılımı olan Shaft 2D programını geliştirmiştir. Çalıșmada, tahkimat desteğinin üzerinde gelişen basınçları tahmin etmek için, 2B kuyu kesiti örneklerinde, farklı kaya kütlesi dayanımları ve farklı arazi yüklemeleri için tasarlanmış bir sayısal çalışma yapmıştır. Sanada ve diğ. (2015) gider tahmini ve zaman kazancı dahil, güvenilir proje yönetimi açısından kuyu inşaatı öncesinde gerçekçi ve doğru şekilde planlanmış kazı döngü sürelerinin geliştirilmesini araştırmışlardır. Çalışmada, Japonya'da gelecekte yapılacak herhangi bir kuyu inşaatına uygulanmak üzere referans alınan iş planı ve termin ve hesaplamalarının optimizasyonuna bir değerlendirme sağlaması amacıyla, Mizunami Yeraltı Araştırma Laboratuvarı Havalandırma Kuyusunun kazısı esnasında kaydedilen gerçek döngü süresi analizi ve dizayn aşamasında geliştirilen planlanmış döngü süreleri karşılaştırılmıştır. Geniş ve Acun (2015) çalışmalarında, Amasra-Bartın'da özel sektör tarafından yürütülen Amasra $B$ taşkömürü üretim projesi kapsamında açılan üç kuyudan biri olan Tarlaağzı üretim kuyusunun duraylılığını analitik ve sayısal gerilme çözümlemesi yöntemleri kullanılarak incelenmişler ve elde edilen sonuçları karşılaştırmışlardır. Genellikle orta ve yüksek dayanımlı kaya birimlerinde açlan kuyuda herhangi bir duraysızlı probleminin bulunmadığını ortaya koymuşlardır. Vasilyev, Kholmskiy ve Sankovsky (2018) yaptıkları çalışmada, Rusya'da bulunan Kochkarskoye altın madeninde iki boyutlu düzlemde nakliyat maliyetlerini dikkate alarak en uygun maden kuyusunun yerini belirlemişlerdir. Hussaini ve Özkan (2018) çalışmalarında, $9 \mathrm{~m}$ çaplı ve $900 \mathrm{~m}$ derinliğe ulaşan düşey bir kuyunun $\mathrm{C} 20$ beton kalitesinde optimum beton tahkimat kalınlıklarını 100 farklı senaryo model üzerinde iki boyutlu sayısal analizler ile Phase2 yazılımı ile belirlemişlerdir. 


\section{Kınık-Elmadere Linyit Projesinin Tanıtımı}

Soma Eynez sahası hem kalite hem de kaynak miktarı açısından tartışmasız Türkiye'nin en önemli linyit varlığıdır. Soma bölgesinde 1960'lı yıllardan bu yana açık ocak madenciliği ile linyit üretimi yapılmaktadır. Ancak sahada açık ocak işletmeciliğine uygun linyit rezervi tükenmekle birlikte yer altı madenciliği ile yapılan üretim son yıllarda önemli ölçüde artmıştır (Ünver ve diğ., 2017).

Polyak Eynez Enerji Üretim Madencilik San. ve Tic. A.Ş. tarafından İzmir ilinde Kınık İlçesi'ne yaklaşık $9 \mathrm{~km}$ mesafede yer alan linyit sahası için 2011 yılında yeraltı ișletme projesi hazırlanmıș ve sahada sondaj ve jeofizik çalışmaları yapılarak 2014 yılında hazırlık çalışmalarına başlanmıştır. Proje sahası, Elmadere Köyü'nün kuş uçumu 750 m güneyinde ve en yakın yerleşim yeri olan Çınarlı Mahallesi'nin $500 \mathrm{~m}$ güneydoğusunda yer almaktadır. Sahada sondaj çalışmaları ile rezerv çalışmaları yapılmış olup yaklaşık 247,6 milyon ton linyit rezervi tespit edilmiştir.

Proje sahasında yaklaşık $3500 \mathrm{~m}$ uzunluğunda faydalı kesiti $24 \mathrm{~m}^{2}$ olan desandre ile iki adet $800 \mathrm{~m}$ derinliğinde ve net $8 \mathrm{~m}$ çapında kuyuların açılması planlanmış ve kazı çalışmalarına geçilmiştir (Şekil 2). Mevcut desandre ve kuyu çalışmaları devam etmektedir. Servis kuyusu açılması tamamlandıktan sonra kuyu içi giydirme işlemleri yaklaşı 6-8 ay sürmesi planlanmaktadır. Desandre ve havalandırma kuyusu birleștiğinde ilk aşamada desandre ağzına kılçık galerisi yapılması ve ana fan sisteminin bu galeriye kurulması planlanmaktadır. $\mathrm{Bu}$ durumda, pis hava çıkışı desandreden, temiz hava girişi ise havalandırma kuyusundan olacaktır. Personel ve malzeme nakli temiz hava girișinin olduğu havalandırma kuyusundan olacaktır. İşletme yönteminde ise ocağa temiz hava girişi üretim desandresi ve servis kuyularından olacaktır. Ocakta kirlenen hava havalandırma kuyusuna teçhiz edilecek olan emici aspiratörler ile ocaktan emilecektir. Buna ek olarak, gerek görülmesi halinde veya acil durumlarda kullanılabilecek șekilde üretim desandresi baca ağzına da emici fan kurulacak olup servis kuyusunun devrede olmadığı hallerde hava yönü havalandırma kuyusundan temiz hava girişi, desandreden kirli hava çıkışı olacak şekilde yönlendirilerek üretimin gerçekleştirilmesi sağlanacaktır. Ocağa personel ve malzeme girişleri servis kuyularından gerçekleştirilecektir.

Proje kapsamında tüvenan kömürün çıkarılması, yeraltı ocak işletmeciliği yöntemiyle yapılacaktır. Proje kapsamında üretim planı yıllara göre değişiklik gösterecek olup ilk yıl 200 bin ton, 2. yll 1 milyon ton, 3. ve 4 . yll ise 2,5 milyon ton ve 5 . yll 5 milyon ton üretim yapılarak tam kapasiteye ulaşlacaktır. Proje üretim sahasında kömür damarları oldukça kalın olup işletilebilir kömür kalınlıkları 6 ile 27 metre arasında değişmektedir. Yapılan çalışmalar sonucunda üretim sahasındaki kömürün göçebilirlik derecesi "iyi” olarak sınıflandırılmış ve üretim için (çok katlı) tam mekanize arkadan göçertmeli üretim yöntemi önerilmiştir. Projede, 16 m' ye kadar olan kömür kalınlıklarında tek katlı, 16 m' den daha kalın damarlarda çok katlı üretimin uygulanabilir olduğu belirtilmiștir. Yapılacak diğer panolar tek seferde kazanılacaktır. Bu bilgiler ışığında üretimin tam mekanize geri dönümlü arkadan göçertmeli uzun ayak yöntemi ile yapılması kararlaştırılmıştır.

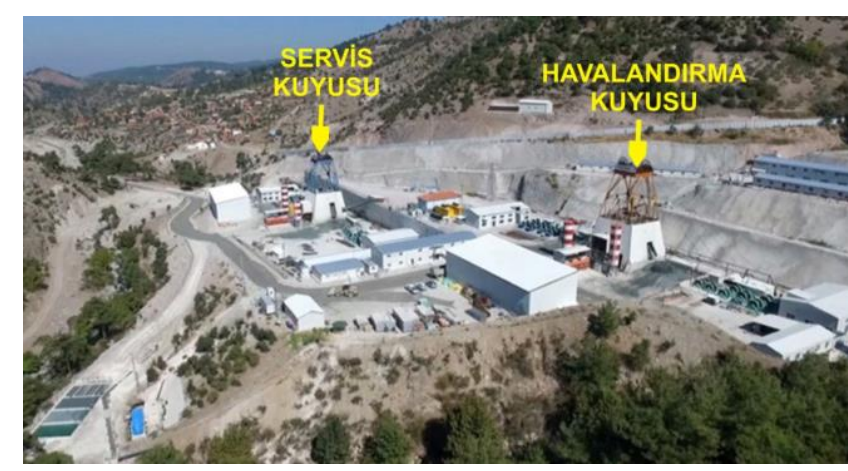

Şekil 2. Havalandırma ve Servis Kuyusu Kazı Bölgesi

\section{Bölgenin Jeolojisi}

Soma yöresine ait genelleştirilmiş stratigrafik kesit görüntüsü Şekil 3'de verilmektedir. İçerisinde kömür damarlarının da yer aldığı farklı litolojik birimler bulunmaktadır. Bu birimler yukarıdan aşağıya doğru; Serizitli kumtaşı-silttaşı-alacalı kil (P1), Orta linyit horizonu (KM3), Kireçtaşı (M3), Marn (M2), Alt linyit horizonu (KM2), Çakıltaşı-Kumtaşı-Kil (M1) ve Taban: Kristalize kireçtaşı-grovak (Tmk-Tmgr) olmak üzere siralanmaktadır (Ünver ve diğ., 2017).

Firma tarafindan hazırlanan işletme projesinde belirtildiği üzere, sahada linyit hariç tüm litolojik birimlerden laboratuvar testleri için karot örnekleri alınmış, arazi çalışmaları ve laboratuvar deneylerinden elde edilen veriler doğrultusunda kaya kütle sınıflaması ve kaya kütle dayanımı parametreleri belirlenmiştir. Havzadaki kaya kütlelerinin sınıflandırılması ve jeomekanik parametrelerin belirlenmesine yönelik çalışmada elde edilen sonuçlar Tablo 2'de verilmiştir. Projede litolojik birimlere göre hesaplanan Q sinıflama sistemi değeri de tabloda gösterilmiş ve buna göre birimler kaya sınıfı olarak çok zayıf-zayıf-orta kaya sinıfina girmektedir. 


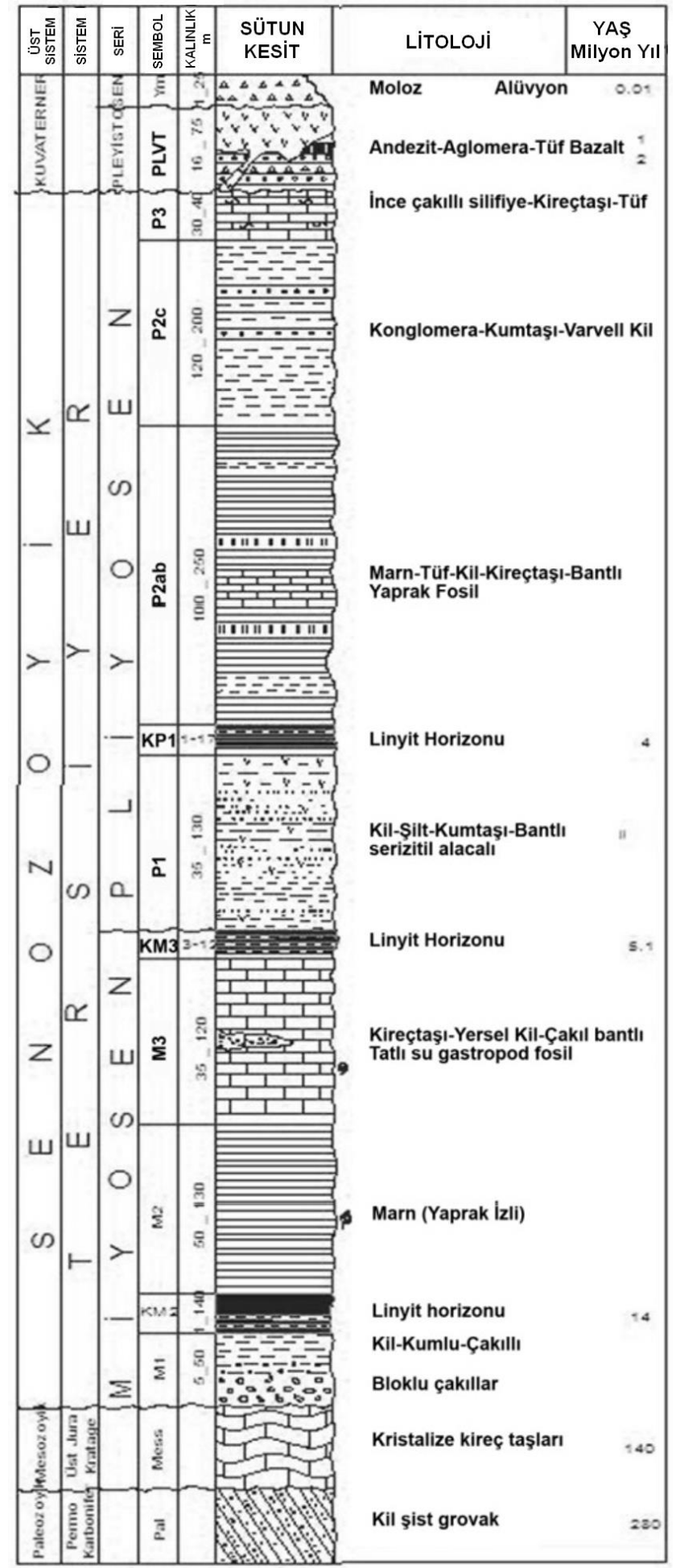

Şekil 3. Soma Yöresine Ait Genelleştirilmiş Stratigrafik Kesit (Nebert, 1978 ve Gürsoy, 1990'dan değiştirilerek alınmıştır)
Tablo 2

İşletme Projesinde Belirtilen Laboratuvar Test Sonuçları (Özkan, 2019)

\begin{tabular}{|c|c|c|c|c|c|}
\hline Litolojik Birim & P2c & P2ab & P1 & $\begin{array}{c}\text { M3 } \\
\text { Kireçtaşı } \\
\end{array}$ & $\begin{array}{c}\text { M2 } \\
\text { Marn } \\
\end{array}$ \\
\hline $\begin{array}{l}\text { Tek Eksenli } \\
\text { Basınç Dayanımı, } \\
\sigma_{c}(\mathrm{MPa})\end{array}$ & $\begin{array}{l}1.4- \\
14.9\end{array}$ & $\begin{array}{c}2.8- \\
109.4\end{array}$ & $\begin{array}{l}8.6- \\
36.7\end{array}$ & $\begin{array}{l}17.1- \\
73.1\end{array}$ & $\begin{array}{l}20.6- \\
108.6\end{array}$ \\
\hline $\begin{array}{l}\text { Elastisite Modülü, } \\
\text { E, (MPa) }\end{array}$ & $\begin{array}{l}126- \\
3652\end{array}$ & $\begin{array}{c}334- \\
14185\end{array}$ & $\begin{array}{l}732- \\
7282\end{array}$ & $\begin{array}{l}8480- \\
24372 \\
\end{array}$ & $\begin{array}{l}2412- \\
32876 \\
\end{array}$ \\
\hline Poisson Oranı, $v$ & $\begin{array}{l}0.04- \\
0.48\end{array}$ & $\begin{array}{l}0.03- \\
0.46\end{array}$ & $\begin{array}{c}0.13- \\
0.45\end{array}$ & $\begin{array}{l}0.03- \\
0.21\end{array}$ & $\begin{array}{c}0.04- \\
0.12\end{array}$ \\
\hline $\begin{array}{l}\text { Çekme Dayanımı, } \\
\text { ot (MPa) }\end{array}$ & $\begin{array}{c}0.53- \\
2.62 \\
\end{array}$ & $\begin{array}{c}0.40- \\
9.79 \\
\end{array}$ & $\begin{array}{c}0.21- \\
5.34 \\
\end{array}$ & $\begin{array}{c}0.44- \\
6.84 \\
\end{array}$ & $\begin{array}{l}1.33- \\
7.79 \\
\end{array}$ \\
\hline $\begin{array}{l}\text { Jeolojik Dayanım } \\
\text { İndeksi, (GSI) }\end{array}$ & 18 & 57 & 18 & 60 & 60 \\
\hline \multirow[b]{2}{*}{ Q Değeri } & $\begin{array}{c}0.69- \\
1.02 \\
\end{array}$ & $\begin{array}{l}2.10- \\
2.97 \\
\end{array}$ & $\begin{array}{c}0.76- \\
1.15 \\
\end{array}$ & $1.60-4.55$ & $\begin{array}{c}2.85- \\
4.50\end{array}$ \\
\hline & $\begin{array}{c}\text { çok } \\
\text { zayıf }\end{array}$ & zaylf & $\begin{array}{r}\text { çok } \\
\text { zayıf- } \\
\text { zayıf } \\
\end{array}$ & $\begin{array}{l}\text { zaylf } \\
\text { orta }\end{array}$ & $\begin{array}{l}\text { zaylf } \\
\text { orta }\end{array}$ \\
\hline
\end{tabular}

\section{Havalandırma ve Servis Kuyusu Açma Çalışmaları}

Yeraltı maden ocaklarında kuyu kesitinin belirlenmesi önemli bir konudur. Kesit belirlenirken yeraltında kullanılacak ekipman ve malzeme boyutları, üretim ve hava miktarı gibi hususlar dikkate alınmaktadır. Yeraltına nakliyatı yapılacak uzun ayak ekipmanlarının boyutları ve kurulacak nihai ihraç sistemi sebebiyle, servis kuyusunun ve yeraltına yeterli hava miktarının verilebilmesi için ana havalandırmada kullanılacak emici fanların kurulacağı havalandırma kuyusunun net çaplarının 8 m olması kararlaştırılmıştır.

Linyit kömürü üretimi için $8 \mathrm{~m}$ çapında bir adet havalandırma ve bir adet servis kuyusu olmak üzere, açlacak olan iki adet derin maden kuyularına yönelik yer belirleme çalışmaları yapılmıştır. Kuyu yerlerinin seçimi sırasında arazideki jeoteknik, jeomekanik, hidrojeolojik unsurlar ele alınmıştır. Bu çalışmalar sırasında hem litolojik faktörler hem de çıkarılan cevherin nakliyesi sırasında oluşabilecek sorunlar değerlendirilerek en uygun yer belirleme çalışması yapılmıştır. Topografik ve hidrolojik şartlar, formasyonun jeomekanik parametreleri, kuyu emniyet topuğu miktarı, üretim miktarı ve ana nakliyat yollarının servis ömürleri, uygulanacak yeraltı nakliyat türü faktörlerinin hepsini içine alabilecek optimum kuyu yerlerinin seçimi yapılmıştır. Değerlendirmeler sonucunda linyit sahasında havalandırma ve servis kuyusunun yerleri Şekil 4'te verilmiştir.

Kınık-Elmadere linyit sahasında, havalandırma ve servis kuyularının kazısına başlanmadan önce her iki kuyunun merkezinden araştırma amaçlı pilot sondajlar (KGT-1 ve KGT-2) yapılmıştır. Derinlikleri 860,5 m olan KGT-1 sondajı ve $865 \mathrm{~m}$ olan KGT-2 sondajının kestiği ana birimler, aglomera, tüfit, andezit, kumtaşı-silttaşıkiltaşı-marn ardalanması, konglomera, üst linyit 
horizonu, kiltaşı, kireçtaşı, marn, alt linyit horizonu, kiltaşı, grovak ve şistler şeklinde sınıflandırılabilmektedir (Şekil 5). Pilot sondajlar sonucunda arazideki jeoteknik, jeomekanik, hidrojeolojik unsurlar belirlenmiştir. Kazı faaliyeti öncesinde, kuyu açlacak bölgenin $700 \mathrm{~m}$ altında basınçlı akiferin olması sebebiyle, kuyu yeri seçimi tekrar gözden geçirilmiş, sahanın topoğrafyası, işletme ruhsatı, yasal izinler ve tesis kurulumları için yapılmış fizibilite ve planlama çalışmaları tekrar gözden geçirildikten sonra, linyit kömür üretim projesi için kuyu yerinin değiştirilmesinin mümkün olamayacağı düșünülerek akifer ile mücadele kararı alınmıştır.

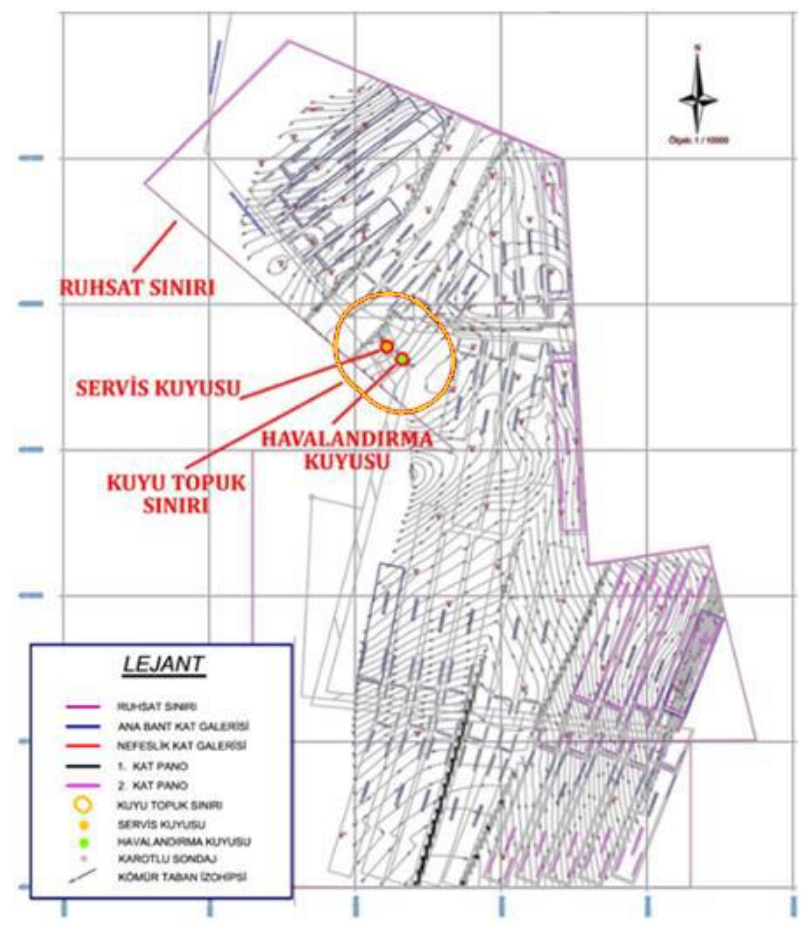

Şekil 4. Kuyuların Yerleri

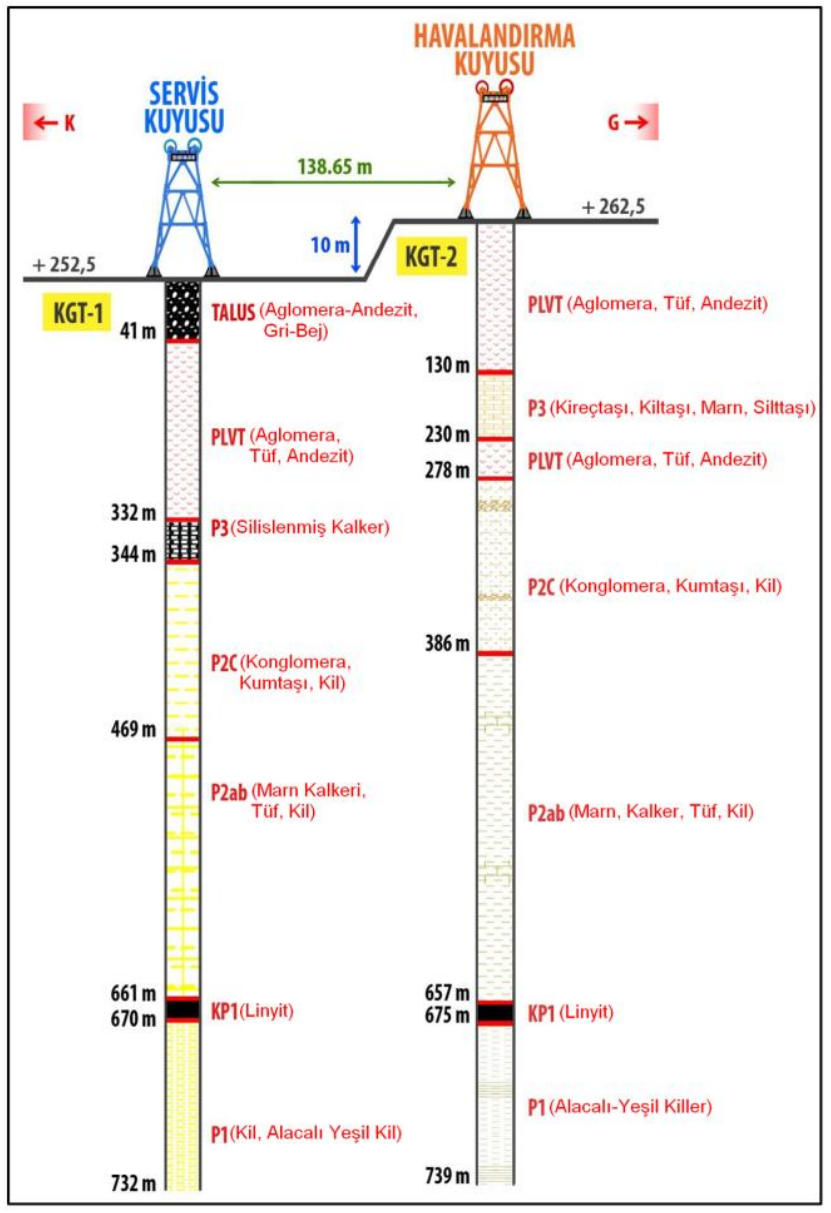

Şekil 5. KGT-1 ve KGT-2 Pilot Sondajlarının Kestiği Birimler (ölçeksiz)

\section{1. Ön Enjeksiyon}

Kuyuların kazı faaliyetlerine başlamadan önce her iki kuyunun merkezinden yapılan pilot sondajlar neticesinde 0-350 $\mathrm{m}$ arasında geçilecek formasyonun andezit-tüf geçirimli bir tabaka olduğu belirlenmiştir. $\mathrm{Bu}$ nedenle kuyu kazılarına başlamadan önce yerüstünden kuyuların cidarları dışına gelecek şekilde ilk 350 m derinliğe kadar susuzlaştırma planlanmıştır. Susuzlaştırma için sistematik delgi ve çimento enjeksiyonu yapılmıştır. Havalandırma kuyusunda, 350 m derinliğe kadar yapılan enjeksiyonlarda toplam 403 ton, servis kuyusunda ise 218 ton çimento kullanılmıştır. Havalandırma kuyusunda yapılan ön enjeksiyon uygulamasında kullanılan çimento miktarı, servis kuyusundaki enjeksiyonda kullanılan çimento miktarından yaklaşık iki kat fazladır. Bunun nedeni, havalandırma kuyusunun ilk 130 metreden sonraki 100 metrelik bölümü P3 litoloji biriminde geçmektedir. P3 birimi PLVT volkanik birimine göre daha faylı, çatlaklı ve gevşek bir birimdir. Servis kuyusunda P3 birimi sadece 12 m olarak geçilmektedir. P3 biriminde yapılan enjeksiyon çalışmalarında oldukça fazla miktarda çimento kullanılmıştır. Havalandırma kuyusunda 
yapılan enjeksiyon delgileri başlangıçta $350 \mathrm{~m}$ olarak planlanmasında rağmen $150 \mathrm{~m}$ seviyelerinde sonlandırılmak zorunda kalınıștır. Her iki kuyuda da enjeksiyon sonrasında yapılan basınçlı su testleri ile formasyonların geçirimsiz olduğu tespit edilmiştir.

\subsection{Kuyu Ekipmanları}

Havalandırma kuyusunda, Kuzey yöndeki ana vinç motoru $1600 \mathrm{~kW}$ gücünde ve çift tamburlu olup, Güney yöndeki ana vinç motoru $1250 \mathrm{~kW}$ gücünde ve tek tamburludur. Havalandirma kuyusunda, kuyu kazısı tamamlandıktan sonra kova-kafes değişimi yapılacak olması nedeniyle Kuzey yönde çift tamburlu ana vinç kurulumu yapılmıştır. Servis kuyusunda ise, Kuzey ve Güney yönde $1250 \mathrm{~kW}$ gücünde ve tek tamburlu ana vinç motorları kurulumu yapılmıştır. Kuyularda ana vinçlerin yanı sıra, kuyu kazı platformu, kuyu beton kalıbı, kaktüs kepçeler, basınçlı hava borusu, elektrik kablosu, kurtarma kapsülü ve vantüpün bağlı olduğu yardımcı vinçler bulunmaktadır. Her iki kuyuda Kuzey ve Güney yönde $45 \mathrm{~kW}$ gücünde 6 adet, $30 \mathrm{~kW}$ gücünde 8 adet ve $22 \mathrm{~kW}$ gücünde 2 adet yardımcı vinç motorları kurulumu yapılmıştır.

Havalandırma ve servis kuyuları aynı sahada yer aldığından, ortak bir basınçlı hava sistemi düşünülerek sahaya bir adet kompresör binası kurulmuștur. Kompresör binasına, MM-250 modeldeki 6 adet kompresör $(250 \mathrm{~kW})$ ve SA-125A modeldeki 1 adet kompresör $(125 \mathrm{~kW})$ yerleştirilmiştir. Maksimum hava basincı $260 \mathrm{~m}^{3} / \mathrm{dk}$.'dır.

Havalandırma ve servis kuyularının kuyu içi havalandırmasında, her iki kuyu başında kuyu içine temiz hava verilebilmesi için ortalama $10 \mathrm{~m}^{3} / \mathrm{s}$ kapasiteli $2 \times 45 \mathrm{~kW}$ gücünde birer adet tali fan motorları kullanılmaktadır. Her iki kuyu için, herhangi bir arızaya karşı aynı güç ve kapasitede birer adet de $2 \times 45$ kW'lık yedek tali fan motorları bulunmaktadır. Tali fanlara, 1000 mm çapında vantüpler bağlanarak, kazı sırasında kuyu dibi çalışma bölgesine (kazı arınına) yeterli miktarda temiz hava iletilmiştir. $1000 \mathrm{~mm}$ 'lik vantüpler kuyu kazısı sırasında, kazı arınından 10 m mesafede olacak şekilde kazıyı takip etmiştir.

\subsection{Kuyu Kazısı}

Kuyu kazısı; delme ve patlatma, pasa alımı, demir örme, ölçü alımı ve kalıp indirilmesi, beton dökümü işlerinden oluşmaktadır. Havalandırma ve servis kuyularında, tam ölçekli delme ve patlatma ile kuyu derinleştirmeye başlamadan önce, kazı platformu ve yükleme ünitelerinin kurulabilmesi amaciyla $40 \mathrm{~m}$ ön derinleștirme yapılmıștır. Kuyular, 41 m derinliğe kadar klasik delme ve patlatma metodu ile kazllmıștır. İlerleme delikleri martoperfaratör ile delinmiş ve her $3.6 \mathrm{~m}$ (bir kalıp boyu) ilerleme için iki atım yapılmıştır.
Pasa, kovalara kaktüs kepçelerle veya paletli yükleyici ile yüklenmiștir. Daha sonra 3 katlı olan kazı platformunun kurulumuna geçilmiştir.

Şekil 6'da verilen kazı platformunun birinci katında iki adet sinyalci personel bulunmakta ve kuyu dibi ile iletişim kurulmaktadır. Birinci kat altına montajlanan 4 adet lamba ile arın aydınlatması sağlanmış ve ayrıca iki adet kaktüs kepçenin birinci katta kurulumu yapılmıştır. İkinci katta, ihtiyaç olduğunda kademeli su pompaları kurulumu yapılmaktadır. Üçüncü katta ise, ikinci katta kademeli su pompalarının kurulumu yapıldığında, pompaların emişlerine verilecek suyun çöktürülmesi amaçlı tank kurulumları yapılmaktadır.

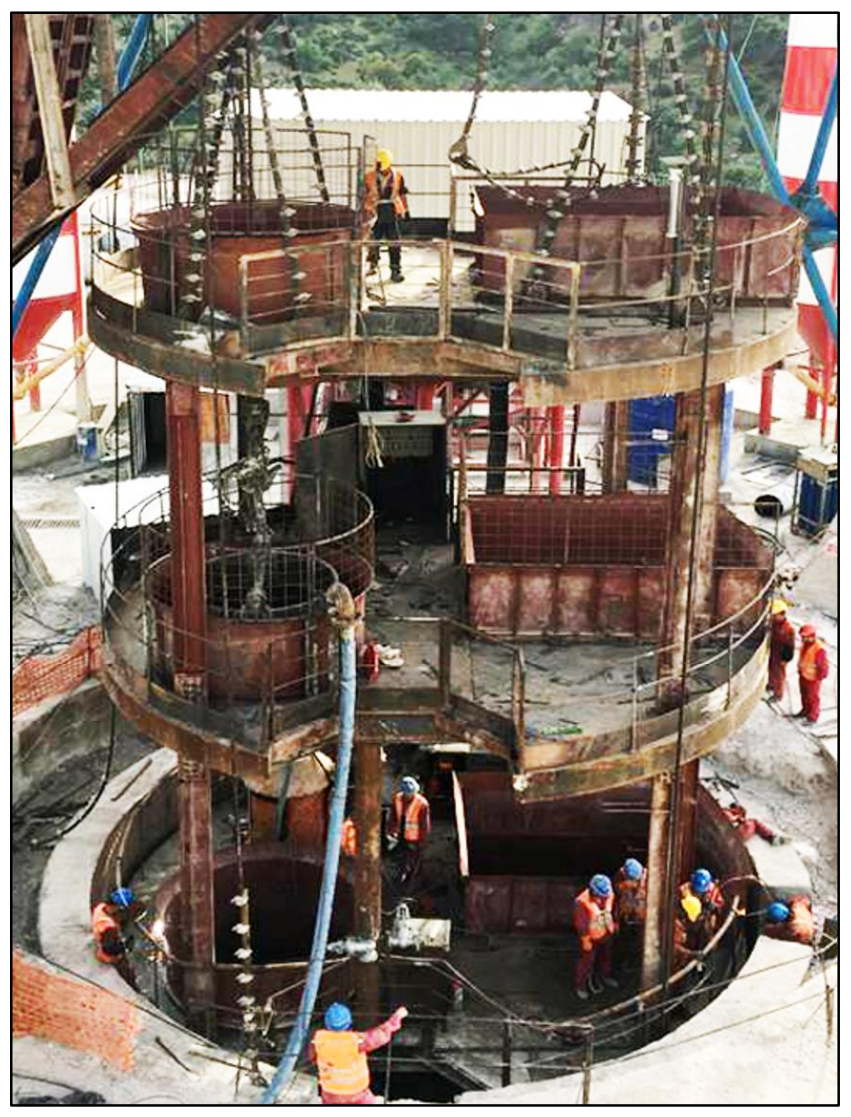

Şekil 6. Kazı Platformunun Kurulumu

\subsubsection{Delik Delme}

Ön derinleștirme sonrasında kuyu kazısında ilerleme deliklerini delme işleminde; şemsiye tipi delici kullanılmıştır. Üzerinde 8 adet pnömatik delici tabanca (martoperfaratör) bulunan makine ile delikler 4-4.5 m'lik burgularla 45-55 mm çapında delinmiștir. Delik boyları 3.5-4.2 m arasında değişmektedir. Şemsiye tipi delicinin kuyu tabanına indirilmesi ve kurulumu ile başlayan ilerleme deliklerinin delinmesi ișlemi, delik delme işleminin tamamlanmasının ardından şemsiye tipi delicinin tekrar kuyudan çıkarılmasıyla tamamlanmaktadır. Her bir manevra süresi kuyu 
derinliğine bağlı olmakla birlikte ortalama 45 dakika olarak ölçülmüştür. Kuyu kazıları sırasında karşılaşılan formasyona göre delik sayıları değişiklik göstermiș ve uygulanan delik sayıları ve ortalama delik delme hızları Tablo 3'te verilmiştir.

Havalandırma ve servis kuyularında ilerleme miktarına bağlı olarak kullanılmış olan delik düzenleri paralel orta çekmedir. Tüm yüzey şeklinde ilerleme yapılmıştır. Kuyuların kazısında geçilecek olan formasyona göre ve ilerleme miktarlarındaki artış veya azalma durumunda delik düzenlerinde değişikliklere gidilmiștir. Formasyon dayanımlarının orta olduğu durumlarda $3 \mathrm{~m}$ ve 3,6 m ilerleme yapılmıș, formasyon dayanımlarının düşük olduğu durumda ise kuyu yan cidarından aşırı sökülme ve bir üst beton kalıbının arkasından malzeme akmasını engellemek için 2,5 m ilerleme yapılarak, delik düzeninde delik boyu, delik sayısı ve sırasında azalmaya gidilmiştir.

\subsubsection{Patlatma}

Delik delme işlemi tamamlandıktan sonra, patlayıcı madde kuyu dibine indirilerek, deliklere şarj edilmiştir. Daha sonra sıkılama işlemi uygulanmakta ve sıkılama için 4-12 mm mıcır kullanılmıştır. Kuyularda yapılan patlatmalarda emülsiyon tipi su bazlı patlayıcı madde ve 100 ms gecikmeli NONEL elektriksiz kapsül kullanılmıștır. Arın bağlantılarında 1 den 10 numaraya kadar olan gecikmeli kapsüller ile ilk olarak orta çekme daha sonra tarama delikleri gecikmeli olarak patlatılacak şekilde bağlanmıştır. Arın bağlantılarında kullanılan kapsüllerin numaralandırılması aynı zamanda gecikme miktarını da belirlemektedir. Patlayıcı madde şarjı yapıldıktan sonra, personel kuyudan çıkartılmakta ve kazı platformu uygun patlatma seviyesine (arından 35-40 m yukarı) kadar çekilerek, tüm personel ve donanım kuyudan çıkarılınca patlatma işlemi yer üstünden gerçekleştirilmektedir.

Tablo 3

Kuyu Kazı Çalıșmalarının Performans Verileri

\begin{tabular}{|c|c|c|c|c|c|c|c|c|c|c|c|c|}
\hline $\begin{array}{l}\text { Derinlik } \\
\text { (m) }\end{array}$ & $\begin{array}{c}\text { Litolojik } \\
\text { Birim }\end{array}$ & $\begin{array}{c}\text { Ort. } \\
\text { Delik } \\
\text { Sayısı }\end{array}$ & $\begin{array}{c}\text { Ort. Net } \\
\text { Delik } \\
\text { Delme } \\
\text { Hızı } \\
\text { (m/dk.) }\end{array}$ & $\begin{array}{c}\text { Ort. } \\
\text { Patlayıcı } \\
\text { Madde } \\
\text { Miktarı } \\
\text { (kg) }\end{array}$ & $\begin{array}{c}\text { Ort. } \\
\text { Özgül } \\
\text { Şarj } \\
\left(\mathrm{kg} / \mathrm{m}^{3}\right)\end{array}$ & $\begin{array}{c}\text { Kaya } \\
\text { Saplaması } \\
\text { Sayısı }\end{array}$ & $\begin{array}{c}\text { Bir } \\
\text { Metrede } \\
\text { Kullanılan } \\
\text { Kaya } \\
\text { Saplaması }\end{array}$ & $\begin{array}{l}\text { Çelik } \\
\text { Hasır } \\
\text { Sayısı }\end{array}$ & $\begin{array}{c}\text { Bir } \\
\text { Metrede } \\
\text { Kullanılan } \\
\text { Çelik Hasır }\end{array}$ & $\begin{array}{c}\text { Kalıp } \\
\text { Boyu } \\
(\mathrm{m})\end{array}$ & $\begin{array}{c}\text { Demir } \\
\text { Miktarı } \\
(\mathrm{kg})\end{array}$ & $\begin{array}{c}\text { Beton } \\
\text { Miktarı } \\
\left(\mathrm{m}^{3}\right)\end{array}$ \\
\hline
\end{tabular}

\begin{tabular}{|c|c|c|c|c|c|c|c|c|c|c|c|c|}
\hline \multicolumn{13}{|c|}{ HAVALANDIRMA KUYUSU } \\
\hline $0-41$ & PLVT & 208 & - & 265 & - & - & - & - & - & 3.6 & 65154 & 847 \\
\hline $41-130$ & PLVT & 160 & 2.3 & 368 & 1.5 & 263 & 2.96 & 101 & 1.13 & 3.6 & 147193 & 1769 \\
\hline $130-230$ & P3 & 157 & 1.6 & 281 & 1.4 & 809 & 8.09 & 319 & 3.19 & 2.5 & 176458 & 1947 \\
\hline $230-278$ & PLVT & 148 & 1.7 & 321 & 1.9 & 52 & 1.08 & 20 & 0.42 & 3 & 83538 & 841 \\
\hline $278-386$ & $\mathrm{P} 2 \mathrm{C}$ & 141 & 1.3 & 280 & 1.5 & 741 & 6.86 & 398 & 3.69 & 3 & 184828 & 1981 \\
\hline $386-657$ & $\mathrm{P} 2 \mathrm{ab}$ & 158 & 1.1 & 304 & 1.5 & 1467 & 5.41 & 854 & 3.15 & 3 & 460391 & 4937 \\
\hline $657-675$ & KP1 & 233 & 1.1 & 333 & 1.4 & - & - & - & - & 3 & 59684 & 541 \\
\hline $675-739$ & P1 & 214 & 1.5 & 327 & 1.3 & 46 & 0.72 & 27 & 0.42 & 3 & 218842 & 2240 \\
\hline \multicolumn{13}{|c|}{ SERVIS KUYUSU } \\
\hline $0-41$ & TALUS & 187 & - & 181 & - & - & - & - & - & 3.6 & 66125 & 829 \\
\hline $41-332$ & PLVT & 226 & 1.8 & 317 & 1.8 & 1778 & 6.11 & 704 & 2.42 & 3.6 & 497111 & 5480 \\
\hline $332-344$ & P3 & 172 & 1.5 & 210 & 1.2 & 179 & 14.92 & 90 & 7.5 & 2.5 & 21983 & 218 \\
\hline $344-469$ & $\mathrm{P} 2 \mathrm{C}$ & 165 & 1.2 & 222 & 1.1 & 1115 & 8.92 & 562 & 4.50 & 3 & 208324 & 2213 \\
\hline $469-661$ & $\mathrm{P} 2 \mathrm{ab}$ & 160 & 1.1 & 227 & 1.1 & 634 & 3.3 & 334 & 1.74 & 3 & 333295 & 3507 \\
\hline $661-670$ & KP1 & 172 & 1.4 & 290 & 1.2 & - & - & - & - & 3 & 29842 & 275 \\
\hline $670-732$ & P1 & 208 & 1.5 & 327 & 1.3 & - & - & - & - & 3 & 208895 & 2148 \\
\hline
\end{tabular}

Kuyuların kazısında litolojik birimlere göre havalandırma kuyusu için 739 m ve servis kuyusu için 732 m derinliğe kadar her bir patlatmada kullanılan patlayıcı madde miktarı ve özgül şarj ölçümleri Tablo 3'te verilmiştir. Ölçümler sonucunda havalandırma kuyusu için her bir patlatmada ortalama patlayıcı madde şarj süresi ortalama $105 \mathrm{dk}$. ve her bir patlatmada ortalama $307 \mathrm{~kg}$ patlayıcı madde olarak belirlenmiştir. $739 \mathrm{~m}$ kuyu kazısında $1 \mathrm{~m}^{3}$ kazı için ortalama $1,5 \mathrm{~kg}$ patlayıcı madde kullanılmıştır. Servis kuyusu için ise her bir patlatmada ortalama patlayıcı madde şarj süresi ortalama 113,2 dk. ve her bir patlatmada ortalama $310 \mathrm{~kg}$ patlayıcı madde olarak 
belirlenmiştir. $732 \mathrm{~m}$ kuyu kazısında $1 \mathrm{~m}^{3}$ kazı için ortalama $1.4 \mathrm{~kg}$ patlayıcı madde kullanılmıştır.

\subsubsection{Pasa Yükleme ve Nakliyat}

Patlatma işlemi tamamlandıktan sonra genellikle $4 \mathrm{~m}$ ilerleme sağlanmakta ve yaklaşık $300-350 \mathrm{~m}^{3}$ pasa çıkmaktadır. Patlatma sonrası her iki kuyu içinde ortalama $60 \mathrm{dk}$. kuyu içi havalandırma için beklendikten sonra kazı platformu indirilerek en kısa sürede yükleme ekibi kuyu dibine inmektedir. Daha sonra kazı platformu kuyu tabanından yaklaşık 15 m yukarıda sabitlenerek her biri $0,8 \mathrm{~m}^{3}$ kapasiteli iki adet, basınçlı havayla çalışan kaktüs kepçe ile $5 \mathrm{~m}^{3}$ lük kovalara doldurularak patlatma sonucunda çıkan pasanın nakliyatı gerçekleştirilmiştir. Kuyu kazılarında pasa alımı iki aşamada gerçekleşmiştir. Birinci aşama patlatma sonrası pasa alımı, ikinci aşama ise kalıp betonu dökümü sonrasında pasa alımı şeklindedir. Birinci aşama pasa alımında, bir kalıp boyu ilerleme miktarı kadar pasa alımı yapılmaktadır. İkinci aşmadaki pasa alımında ise kalıp betonu döküldükten sonra kuyu tabanının temizliği yapılarak, ilerleme deliklerinin delinmesi için arının hazır hale getirmesi sağlanmaktadır. Havalandırma kuyusunun kazısında birinci aşama pasa alımı ortalama 338 dakika, ikinci aşama pasa alımı ortalama 163 dakika olarak ölçülürken servis kuyusunun kazısında ise birinci aşama pasa alımı ortalama 286 dakika, ikinci aşama pasa alımı ortalama 182 dakika olarak ölçülmüştür.

\subsubsection{Kuyu Tahkimatı}

Kuyu derinleştikçe, kuyu yan duvarlarında yıkıntılara meydan vermemek için ve kuyunun beklenen ömrü boyunca işleyecek şekilde kalmasını sağlamak için tahkimat yapmak zorunludur. Genellikle tahkimat cinsinin seçimi, kuyu kesitinin şekil ve büyüklügüne, kuyunun derinliğine ve açıldığı formasyonun sağlam veya zayıf olması durumuna göre belirlenmektedir (Köse ve diğ., 2012).

Kuyu açllacak yerlerde yapılan KGT-1 ve KGT-2 sondajlarının jeoteknik etüdlerinden yararlanılarak sondaj derinlikleri boyunca kayaç birimlerinin jeomekanik özellikleri belirlenmiş ve kayaç sınıflandırmaları gerçekleşmiştir. İşletme projesine göre, sondaj derinlikleri boyunca kayaç birimlerinin çok zayıf- zayıf kayaç sınıfında yer aldığı görülmüştür. Modelleme çalışmaları ile kuyuların emniyeti dikkate alınarak beton kalınlıkları $650 \mathrm{~m}$ derinliğe kadar (kazı kesiti $66.44 \mathrm{~m}^{2}$ ) $60 \mathrm{~cm}$ olarak, 650-760 m arası P1 formasyonunun litolojik olarak şişme potansiyeli olan killerden oluştuğu bilindiği için birinci deformasyon

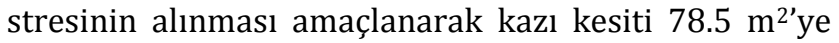
çıkartılarak dış katman $40 \mathrm{~cm}$ ve iç katman $60 \mathrm{~cm}$ olarak, 760-790 m arası $80 \mathrm{~cm}$ olarak belirlenmiştir. Kaplamada yüksek dayanımlı beton kullanılması amaçlanmış beton kalitesi C45, C50 ve C55 seçilmiştir. Kuyu kazılarında beton tahkimatın nihai şeklinin verilmesinde (kuyuların iç çapının $8 \mathrm{~m}$ olarak ayarlanmasında) 15 parçadan oluşan çelik beton kalıpları kullanılmıştır. Beton kalıbının yüksekliği $3,6 \mathrm{~m}, 3,0 \mathrm{~m}$ ve $2,5 \mathrm{~m}$ olarak, ilerleme sırasında geçilecek olan formasyonun dayanım ve süreksizlik özelliklerine bağlı olarak arttırılmış veya azaltılmıştır.

Kuyuların kazısında zayıf formasyon geçişlerinde, yan cidardan akma meydana gelmesini önlemek için $25 \mathrm{~mm}$ çapında ve 3 m uzunluğunda kaya saplaması ve çelik hasır $\left(2 \times 1 \mathrm{~m}^{2}\right)$ kullanılarak ön tahkimat yapılmıştır. Kazı sırasında farklı litolojik birimlerde uygulanan ön tahkimatlarda kullanılan malzeme miktarları Tablo 3'te sunulmuştur. Havalandırma kuyusunun kazısında uygulanan yan cidar ön tahkimatlarında toplam 3378 adet kaya saplaması ve 1719 adet çelik hasır kullanılırken, servis kuyusunun kazısında ise toplam 3706 adet kaya saplaması ve 1690 adet çelik hasır kullanılmıştır.

Pasa alımı ve ön tahkimat işlerinin tamamlanması sonrasinda mahmuz kuyu tabanına indirilerek merkezleme işleminden sonra demir bağlama işine başlanır. Kavislendirilmiş yatay nervürlü demirler 26 mm kalınlığında olup ön sırada ve arka sırada parçaların birleştirilmesiyle kuyu çevresini dönmektedir. Kuyu çevresini birleștirerek oluşturan bu yatay parçalar farklı kalıp boylarında $2.5 \mathrm{~m}$ için 9 sıra, $3 \mathrm{~m}$ için 10 sıra ve 3.6 $\mathrm{m}$ için 11 sıra olacak şekilde alt alta dizilmektedir. 20 mm kalınlığında düșey nervürlü demirler ise kalıp boyuna göre hazırlanmaktadır. Düșey nervürlü demirler bir önceki kalıbın düşey demirlerine manşonlar ile bağlanarak ön ve arka sıra olarak kuyu çevresini dönmektedir.

Demir bağlama işleminin tamamlanmasının ardından kuyu tabanına 0-4 mm boyutlarında 2,6 $\mathrm{m}^{3}$ kum indirilerek mahmuz ile yan cidar arasına kumlama yapılır. Kumlamanın amacı bir sonraki kalıba geçerken, mahmuzun indirilmesi ile arka sıra düșey demir uçlarının beton içinde kalmasını önlemektir. Kumlama işlemi sonrasında beton kalıbı 4 adet yardımcı vinç halatı yardımı ile indirilmeye başlanır ve mahmuz üzerine oturtulur. Beton kalıbının merkez şaküle göre ölçü alınarak mahmuzun üzerine oturtulması işleminden sonra beton dökme işlemine geçilir. Yerüstünde bulunan mobil beton santralinde projeye göre üretilen hazır beton karıșımı, $3 \mathrm{~m}^{3}$ lük beton kovaları ile kuyu içine nakledilerek kazı platformunun en alt katındaki haznelere boşaltılır. Beton, haznelerdeki hortumlar vasıtasıyla beton kalıbındaki 15 adet noktaya sevk edilerek ve kalıp betonu dökme işi gerçekleştirilir.

Havalandırma ve servis kuyularının kazısında, litolojik birimlere göre kullanılan kalıp boyları ve her bir litolojik birimde kullanılan toplam demir ve beton miktarları Tablo 3'te sunulmuştur. Havalandırma kuyusunda tahkimatta kullanılan toplam demir miktarı yaklaşık 
1396,1 ton olup, $1 \mathrm{~m}$ kalıp için ortalama 1,89 ton demir donatı kullanılmıştır. Servis kuyusunda ise toplam demir miktarı yaklaşık 1365,6 ton olup, 1 m kalıp için ortalama 1,87 ton demir donatı kullanılmıştır. Havalandirma kuyusunda toplam $15102 \mathrm{~m}^{3}$, servis kuyusunda ise $14670 \mathrm{~m}^{3}$ beton dökülmüştür. Her 3,6 m ilerlemede $70-75 \mathrm{~m}^{3}, 3 \mathrm{~m}$ ilerlemede $52-53 \mathrm{~m}^{3}, 2.5 \mathrm{~m}$ ilerlemede ortalama $45 \mathrm{~m}^{3}$ beton dökülmüştür. Bir kalıp beton dökme ișlemi ortalama 3,5-4 saatte tamamlanabilmiştir.

\section{Bulgular}

Kınık-Elmadere Linyit projesi kapsamında açlan havalandırma ve servis kuyularının kazısı sırasında yapılan her bir iş için harcanan zamanların ölçümü yapılmıștır. Bu ölçüm sonuçlarından elde edilen veriler ile havalandırma ve servis kuyusu kazısında her bir kalıp ilerlemede, yapılan ardıl işlemlerde harcanan sürelerin farklılıkları Şekil 7 ve 8'de verilmiştir.

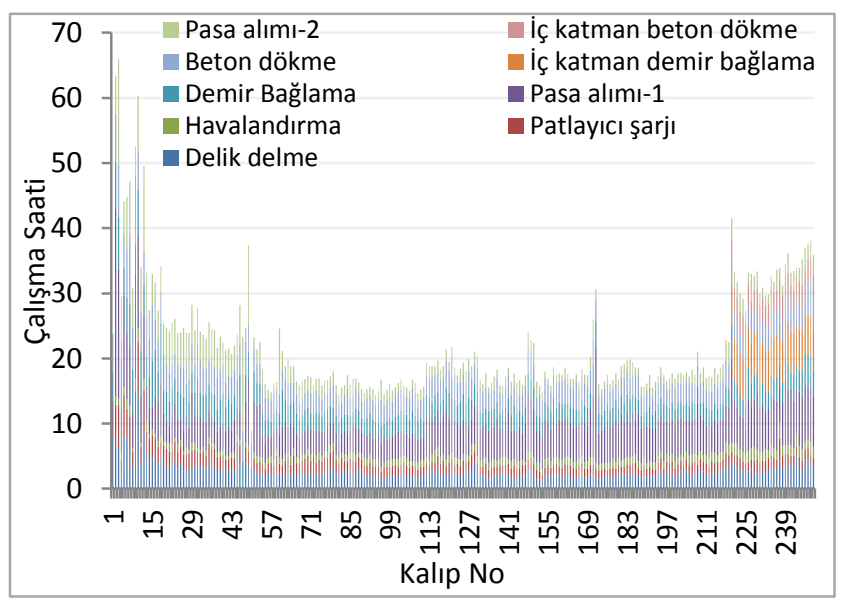

Şekil 7. Havalandırma Kuyusu Kazısı Sırasında Ardıl İşlemler İçin Harcanan Süreler

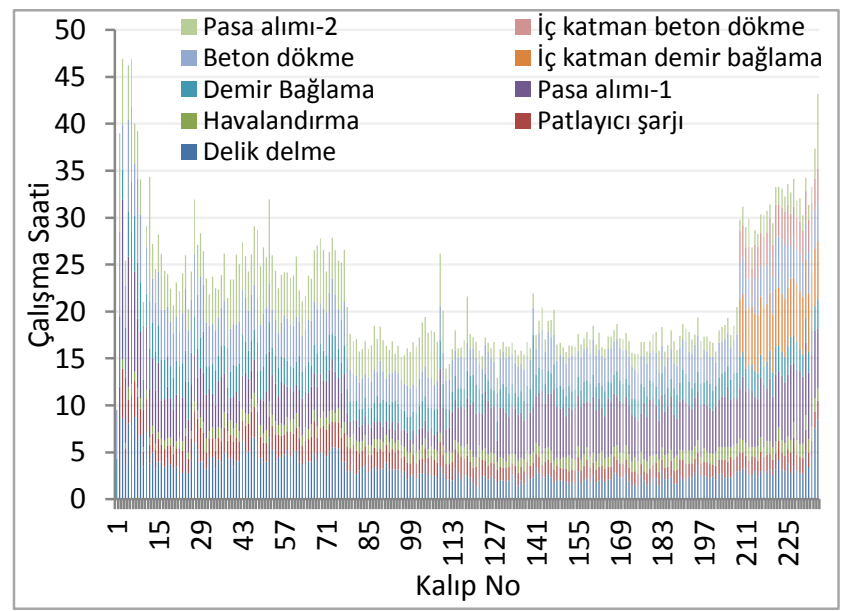

Şekil 8. Servis Kuyusu Kazısı Sırasında Ardıl İşlemler İçin Harcanan Süreler
Şekil 7 ve 8 incelendiğinde, 41 m derinliğe kadar ön derinleştirmede kuyu içi ve yerüstü ekipmanların kurulum aşamasında olmasından dolayı, ilerleme deliklerini delme işinin martoperfaratörler ile yapılması, kalıp boyunun 3,6 m olması nedeniyle ilk 11 adet kalıpta ardıl işlemlerde harcanan sürelerde artış görülmektedir. Daha sonraki kalıplarda kuyu içi ve yerüstü ekipmanların kurulumlarının tamamlanması ile ardıl işlemlerde harcanan sürelerde azalma görülmektedir. Havalandırma kuyusu için 219 nolu ve servis kuyusu için ise 208 nolu kalıptan sonra ise diș katman kazısı olarak ilerleme yapılmış olması nedeniyle kazı kesitindeki artış, ardıl işlemler için harcanan sürelerdeki artışlara etki ettiği görülmüştür.

Havalandırma kuyu kazısına Mart 2016 tarihinde başlanılmış ve Mayıs 2017 tarihi itibariyle 739 m kazısı yapılmıştır. $739 \mathrm{~m}$ ve net $8 \mathrm{~m}$ çapında kuyu kazısı toplam 424 günde gerçekleşmiştir. Bu sürede yapılan her bir işin süreleri ölçülmüş ve toplam süre içindeki yüzde dağılımı belirlemek amacıyla Șekil 9'daki grafik çizilmiştir. Şekil 9 incelendiğinde susuzlaştırma çalışmalarının kuyu kazı performansına olan etkisi ortaya konulmuştur. 739 m kuyu kazısında toplam sürenin \%2'si su deşarjı, \%5'i yan cidar enjeksiyonları, \%1'i taban enjeksiyonu hazırlığı ve \%29'u taban delgi ve enjeksiyonunda harcanmıştır. 9 gün süre su deşarjı, 148 gün susuzlaştırma çalışmaları, 267 gün ise kuyu kazı çalışmaları ile geçmiştir.

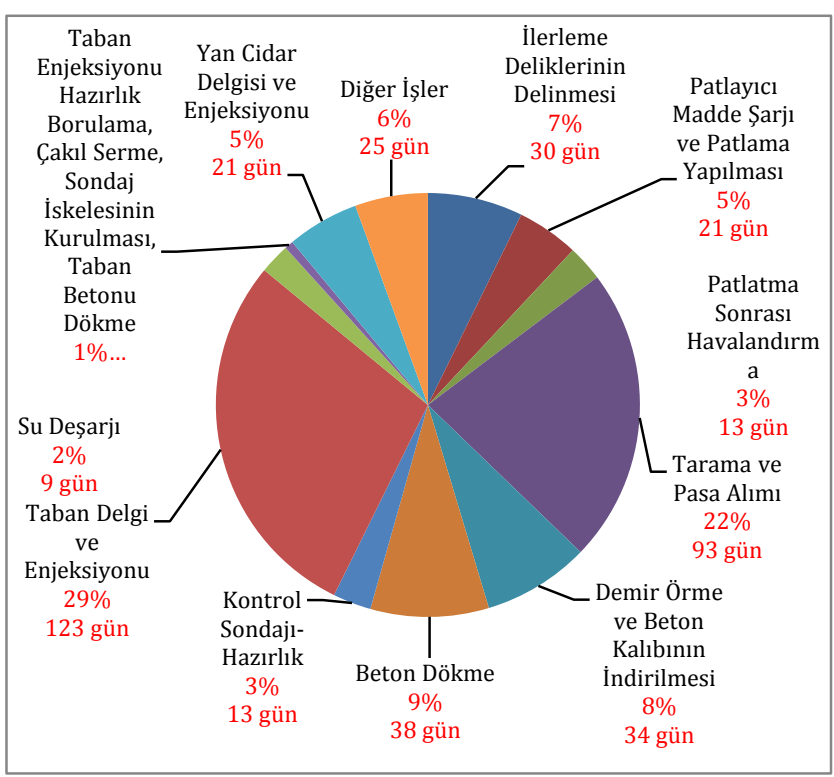

Șekil 9. Havalandırma Kuyusu Kazısında Yapılan İșlerin Dağılımı

Havalandırma kuyusu kazısında aylık ilerlemeleri miktarları Şekil 10'da verilmiştir. Burada, havalandırma kuyusu kazısında maksimum aylı ilerleme 108,7 m ile 
Kasım 2016 tarihinde 550-650 m arasında P2ab biriminde kaydedilmiştir. Havalandırma kuyusunun 700. metrelerine denk gelen 2017 Ocak-Mart döneminde ise akifer bölgesine yaklaşılacağından dolayı taban delgi ve enjeksiyon çalışmaları ile geçmiş herhangi bir ilerleme yapılamamıştır.

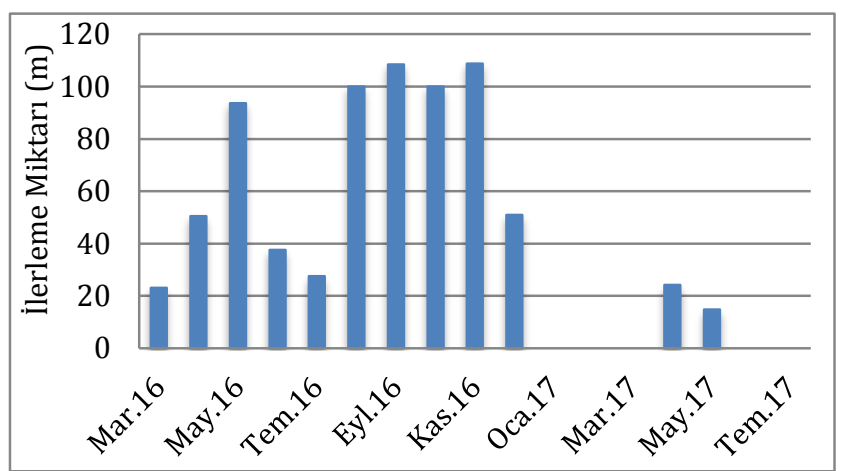

Şekil 10. Havalandırma Kuyusu Aylık İlerleme Miktarları

Servis kuyusu kazısına ise Nisan 2016 tarihinde bașlanılmıș ve Ağustos 2017 tarihi itibariyle $732 \mathrm{~m}$ kazısı yapılmıştır. $732 \mathrm{~m}$ ve net $8 \mathrm{~m}$ çapında kazısı toplam 523 günde gerçekleşmiştir. Bu sürede yapılan her bir işin süreleri ölçülmüş ve toplam süre içindeki yüzde belirlemek amacıyla Şekil 11'deki grafik çizilmiştir.

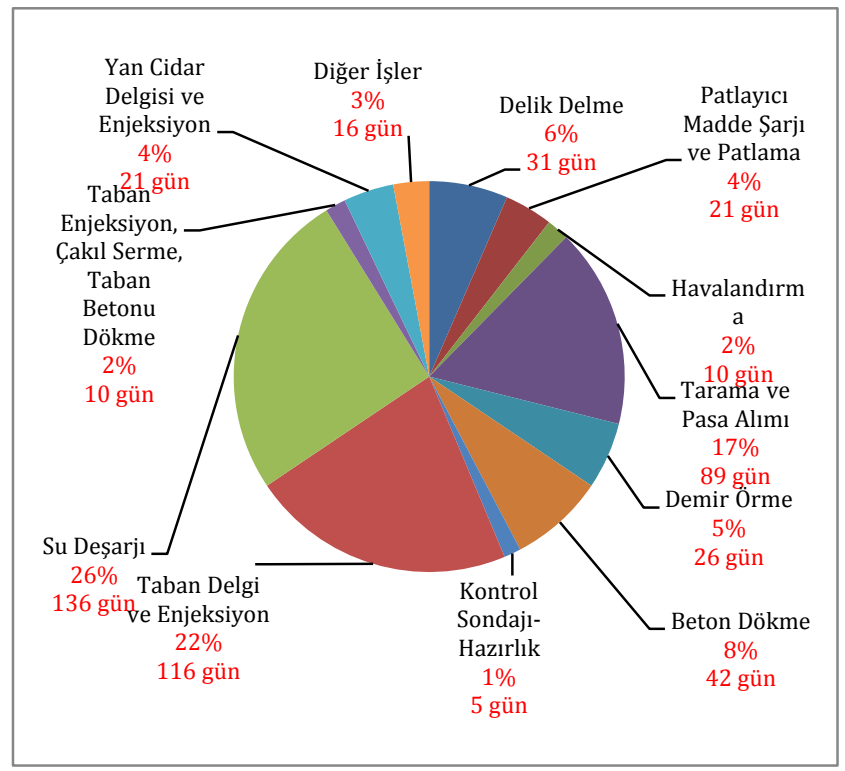

Şekil 11. Servis Kuyusu Kazısında Yapılan İşlerin Dağılımı

Şekil 11 incelendiğinde akifer için su deşarjı ve susuzlaştırma çalıșmalarının kuyu kazı performasına olan etkisi ortaya konulmuştur. 732 m kuyu kazısında toplam sürenin \%26'sı su deșarjı, \%2'si yan cidar enjeksiyonları, \%2'si taban enjeksiyonu hazırlığ ve \%22'si taban delgi ve enjeksiyonunda harcanmıştır. 136 gün süre su deşarjı, 147 gün susuzlaştırma çalışmaları, 240 gün ise kuyu kazı çalışmaları ile geçmiştir.

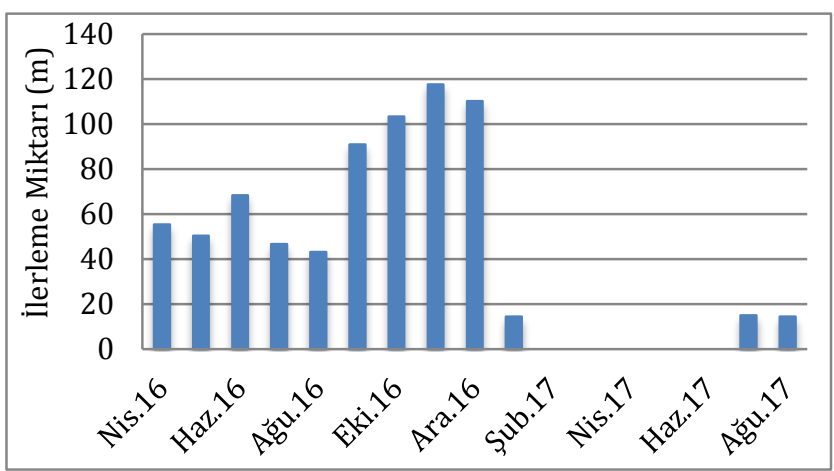

Şekil 12. Servis Kuyusu Aylık İlerleme Miktarları

Servis kuyusu kazısında aylık ilerlemeleri miktarları Şekil 12'de verilmiștir. Burada, servis kuyusu kazısında maksimum aylık ilerleme 117,6 m ile Kasım 2016 tarihinde 464-576 $\mathrm{m}$ arasinda P2ab biriminde kaydedilmiştir. Servis kuyusunun 700. metre seviyesine gelindiğinde 2017 yılı Ocak ayı ortasından Haziran ayı ortasına kadarki dönemde ilerleme yapılmayıp akifer bölgesine yaklaşılacağından dolayı taban delgisi, enjeksiyonu ve su deşarjı çalışmaları yapılmıştır. Bu sonuçlar ışığında her iki kuyu için, formasyon özelliklerinin, ilerleme hızına ve ardıl işlemler için harcanan süreye etkiyen en önemli parametre olduğu sonucuna ulaşmak mümkündür.

\section{Sonuçlar ve Öneriler}

$\mathrm{Bu}$ çalışmada, Polyak Eynez Enerji Üretim Madencilik San. ve Tic. A.Ş. tarafından Kınık-Elmadere'de açılan havalandırma ve servis kuyularının kazı çalışmalarının incelemeleri yapılmıștır. Çalıșmada ele alınan kuyuların açllacağı bölge için, özellikle zayıf kaya ve basınçlı akifer geçişlerinde yapılan uygulamalar ve kuyuların inşa aşamaları ortaya konulmuştur. Kuyuların kazısı öncesi yapılmıș olan sondaj verilerinden hareketle litolojik özellikleri belirlenmiş kayaçlarda, derin maden kuyularının kazısı sırasında her bir litolojik birim için fiili çalışma süreleri ölçülerek gerçek veriler ortaya konulmuştur.

Kuyuların kazı faaliyetlerine bașlamadan önce her iki kuyunun merkezinden yapılan KGT-1 ve KGT-2 pilot sondajlarına göre 0-350 $\mathrm{m}$ arasında geçilecek formasyonun andezit-tüf geçirimli bir tabaka olması nedeniyle her iki kuyuda $350 \mathrm{~m}$ derinliğe kadar susuzlaștırma enjeksiyonu yapılmıştır. Havalandırma 
kuyusunda $350 \quad \mathrm{~m}$ derinliğe kadar yapılan enjeksiyonlarda 403 ton çimento, servis kuyusunda 218 ton çimento kullanılarak susuzlaştırma sağlanmıştır.

Kazı çalışmaları sırasında ise her iki kuyuda susuzlaştırma amacıyla enjeksiyon yapılmıştır. Havalandırma kuyusunda, 739 m kuyu kazısında yapılan çimento enjeksiyonlarında toplam 540 ton çimento kullanılmıştır. Servis kuyusunda, 732 m kuyu kazısında yapılan çimento enjeksiyonlarında toplam 1100 ton çimento kullanılmıştır.

Kuyu kazıları sırasında zayıf formasyon ve aşırı su gelirinin olmasından dolayı bazı sorunlarla karşılașılmaktadır. Bu hususun belirlenmesi amaçıyla sık sık kontrol sondajları yapılmalıdır. Aşırı su geliri ihtimaline karşı kuyu içinde kazı platformunda su pompalarının hazırda bulundurulması gerekmektedir. Aksi takdirde bu yönde bir hazırlık olmaması sonucu kuyu içindeki iş programı gecikmeye uğrayabilmektedir. Kuyu kazılarında zayıf formasyonda akma sorunu ile karşı karşıya gelmemek için kazı yapıldıktan sonra, zaman kaybetmeden emniyet amaçlı püskürtme betonu (shotcrete) atılarak kuyu yan cidarının hava ile teması kesilmeli ve zaman geçmeden çelik hasır ve kaya saplaması ile ön tahkimat uygulaması yapılmalıdir.

Kuyuların kazı faaliyetleri süresince jeomekanik ölçümler alınmakta ve tahkimat tasarımları önceden belirlenmektedir. Fakat projenin uygulanması aşamasında sürekli ölçüm ve gözlemler yapılarak mevcut tasarım parametreleri gözden geçirilmeli ve gerekirse proje revize edilmelidir.

Söz konusu derin maden kuyuları Soma havzasında açılmış ilk ve en derin betonarme kuyuları olma özelliğindedir. Kuyu veya galeri kazısı, kömür üretimi gibi madencilik faaliyetlerine fiili olarak bașlamadan önce, faaliyetin yapılacağı bölgenin jeolojik, jeomekanik ve hidrojeolojik olarak detaylı araştırılması kritik önem taşımaktadır. Polyak Eynez, Kınık-Elmadere linyit kömürü üretim projesi kapsamında, derin maden kuyularının kazısı öncesinde yapılan jeolojik, jeomekanik ve hidrojeolojik çalışmalar sayesinde kuyuların açılacağı bölgede yüzey suları ve basınçlı akifer içinde kuyu içine su gelişi olabileceği önceden belirlenmiștir. Su geliri riski bulunan bölgelerde kuyu veya galeri kazısı gibi büyük hazırlık projelerinin yürütülmesi öncesinde, yeterli kapasitede enjeksiyon ve deşarj pompaları, boru ve kablo şebekelerinin önceden planlanması önem arz etmektedir.

\section{Teşekkür}

$\mathrm{Bu}$ çalışmanın gerçekleştirildiği Polyak Eynez Enerji Üretim Madencilik San. ve Tic. A.Ș.'ne ve projede görevli kuyu başmühendisi, Maden Yüksek Mühendisi Eren SOYER'e, başmühendis yardımcısı Suat TOPCAN ve kuyu mühendisleri, Birol GIDEROĞLU, Çağatay ÇEVEN, Fatih
TEKIN, Murat İNCESU ve Gürhan DEMİ'e teşekkür ederiz.

\section{Araștırmacıların Katkısı}

$\mathrm{Bu}$ araștırmada; İsmail ÖZKAN, bilimsel yayın araştırması, verilerin elde edilmesi ve değerlendirilmesinde; Nazmi ŞENGÜN, çalıșmanın kurgusu, makalenin olușturulması ve sonuçların hazırlanması konularında katkı sağlamışlardır.

\section{Çıkar Çatışması}

Yazarlar tarafından herhangi bir çıkar çatışması beyan edilmemiştir.

\section{Kaynaklar}

Acun, D. (2009). Amasra-Tarlaağzı kuyusu çevre kaya özellikleri ve duraylılığının incelenmesi (Yüksek lisans tezi). Zonguldak Karaelmas Üniversitesi Fen Bilimleri Enstitüsü, Zonguldak.

Alp, F. (2003). Kozlu 1 nolu kuyunun derinleștirilmesinin incelenmesi (Yüksek lisans tezi). Zonguldak Karaelmas Üniversitesi Fen Bilimleri Enstitüsü, Zonguldak.

Bayhan, A., Ölmez, S., ve Arslan, Ş. (2002). Kozlu Uzunmehmet-1 kuyusu tamir ve derinleștirme çalışmaları. Türkiye 13. Kömür Kongresi Bildiriler Kitabı, 219-228, Zonguldak.

Emir, E. (2000). G.L.I. Ömerler ocağı hazırlık panosu kuyu kaplama tasarımı (Doktora tezi). Eskișehir Osmangazi Üniversitesi Fen Bilimleri Enstitüsü, Eskişehir.

Geniş, M., ve Acun, D. (2015). Kuyu duraylılığının analitik ve sayısal yöntemler ile karşılaştırmalı bir incelemesi. Cukurova Üniversitesi Mühendislik Mimarlık Fakültesi Dergisi, 30 (2), 201-215. doi: https://doi.org/10.21605/cukurovaummfd.242763

Güler, E. (2013). Farklı kaya kütlelerindeki dairesel maden kuyularının tahkimat tasarımı için bir yöntem (Yüksek lisans tezi). Orta Doğu Teknik Üniversitesi Fen Bilimleri Enstitüsü, Ankara.

Gürsoy, M.E. (1990). Soma Eynez Calıșma Raporu. Ankara: MTA Genel Müdürlüğü, 1-23.

Hussaini, S.S. ve Özkan, İ. (2018). Düşey maden kuyularında beton tahkimat kalınlıklarının belirlenmesine yönelik bir tasarım yaklaşımı. S.Ü. Müh. Bilim ve Tekn. Derg., 6 (1), 14-27. doi: https://doi.org/10.15317/Scitech.2018.112

Köse, H., Gürgen, S., Onargan, T., Yenice, H., ve Aksoy, C.O. (2012). Tünel ve Kuyu Açma. İzmir: Dokuz Eylül 
Üniversitesi Mühendislik Fakültesi Yayınları No: 145.

Lashgari, A., Fouladgar, M.M., Yazdani-Chamzini, A. \& Skibniewski, M.J. (2011). Using an integrated model for shaft sinking method selection. Journal of Civil Engineering and Management, 17 (4), 569-580. doi: http://dx.doi.org/10.3846/13923730.2011.628687

Nebert, K. (1978). Linyit içeren Soma neojen bölgesi, Batı Anadolu. MTA Dergisi, 90, 20-72.

Oruç, M.M. (2012). Kastamonu Küre derin maden kuyusunun yerleşim yeri ve dolayının mühendislik jeolojisi ve jeomekanik değerlendirilmesi (Yüksek lisans tezi). İstanbul Teknik Üniversitesi Fen Bilimleri Enstitüsü, İstanbul.

Özdemir, M. (1998). Derin şaft açma tekniklerinin karşılaştırılması; Bir örnek çalışma-konvansiyonel metod ile şaft açılması (Yüksek lisans tezi). Boğaziçi Üniversitesi Fen Bilimleri Enstitüsü, İstanbul.

Özkan, İ. (2019). Kınık-Elmadere linyit projesi kapsamında havalandırma ve servis kuyusu açma çalışmalarının değerlendirilmesi (Yüksek lisans tezi). Süleyman Demirel Üniversitesi Fen Bilimleri Enstitüsü, Isparta.

Read, H.W., \& Napier, L.G.D. (1994). Projectmanagement, and the design of shaft-sinking projects. Journal of the South African Institute of Mining and Metallurgy, 94 (7), 147-171. Erişim adresi: $\quad$ https://journals.co.za/content/saimm /94/7/AJA0038223X 2278

Saltoğlu, S. (1976). Madenlerde Hazırlık ve Kazı İşleri. İstanbul: İstanbul Teknik Üniversite Matbaası.

Sanada, H., Sato, T., Horiuchi, Y., Mikake, S., Okihara, M., Yahagi, R., \& Kobayashi, S. (2015). Excavation cycle times recorded during sinking of a deep shaft in crystalline rock - a case example at ventilation shaft of Mizunami URL, Japan. Tunnelling and Underground Space Technology, 50, 68-78. doi: https://doi.org/10.1016/j.tust.2015.06.012

Ünver, B., Hindistan, M.A., Tercan, A.E., Ertunç, G., Ünal, M.S., Kıllıŏ̆lu, S.Y., ve Atalay, F., (2017). Soma eynez kömür sahasi için farkli bir üretim yöntemi önerisi. Madencilik, 56 (1), 5-12. Erişim adresi: https://dergipark.org.tr/tr/download/articlefile/374442

Vasilyev, V.E., Kholmskiy, A.V., \& Sankovsky, A.A., (2018). Determination of main vertical ore-lift shaft location in two planes. IOP Conf. Series: Earth and Environmental Science, 194, 082043, 1-5. doi: https://doi.org/10.1088/1755-1315/194/8/ $\underline{082043}$ 